\title{
"Off-line": The 2004 European parliamentary elections on television news in the enlarged Europe
}

\author{
Claes H. de Vreese ${ }^{\mathrm{a}, *}$, Susan Banducci ${ }^{\mathrm{b}, \mathrm{c}}$, Holli A. Semetko ${ }^{\mathrm{d}}$ and Hajo G. Boomgaarden ${ }^{\mathrm{a}}$ \\ ${ }^{a}$ University of Amsterdam, Amsterdam, the Netherlands \\ ${ }^{\mathrm{b}}$ Universiteit Enschede, Enschede, the Netherlands \\ ${ }^{\mathrm{c}}$ TexasTech, Lubbock, Texas, USA \\ ${ }^{\mathrm{d}}$ Emory University, Atlanta, USA
}

\begin{abstract}
We outline the competitive television news market in the enlarged European Union (EU) and demonstrate the continued importance of traditional media, in particular television, in the context of proliferation in choice of news sources, including on-line news services. Drawing upon a content analysis of the most widely watched evening television news programs in each of the EU countries, we find that on average, EU news in 2004 was more visible in the new member states than in the old member states. The level of coverage in the old member states was slightly higher in 2004 compared to 1999. Looking at individual countries there was considerable variation with some countries (e.g., Greece, Denmark, Slovakia, and Austria) devoting about $20 \%$ of the news to the elections and others (e.g., Germany, Belgium, and the Czech Republic) devoting about $5 \%$ or less to the elections.
\end{abstract}

\section{Introduction}

To provide a wider backdrop and context for this Special Issue's focus on the Internet, the current article looks at the news and information environment as provided by a 'traditional' medium, television. The 2004 elections for the European Parliament (EP), taking place in the aftermath of the May 2004 enlargement of the EU with ten new members, constituted what could be described as the largest ever exercise in democracy. More than 350 million eligible voters were largely dependent upon the media, both 'new' and 'traditional', to receive information about the elections. After all, most citizens today experience politics primarily through the media [2] and this is particularly so in the case of somewhat distant 'European' political issues [6].

In this article, we first assess the information environment in which the elections took place. We provide an overview of the broadcasting market in the EU-25. We then turn to the use of different information sources by citizens across Europe. While the 2004 elections were perhaps the first EP elections in which the Internet played a role, the vast majority of citizens still rely on 'traditional' media for information about EU politics in general and the EP elections in particular. We finally report key findings from a

\footnotetext{
${ }^{*}$ Corresponding author: Claes H. de Vreese, Professor and Chair of Political Communication, Department of Communication Science, The Amsterdam School of Communications Research ASCoR, University of Amsterdam, Kloveniersburgwal 48, 1012 CX Amsterdam, The Netherlands. Tel.: +31 20525 2426; Fax: +31 20525 3681; E-mail: c.h.devreese@ uva.nl.
} 
large-scale content analysis of the news media's coverage of the EP elections. We specifically analyze the visibility of the elections in television news to assess the information available to citizens across Europe. We conclude by outlining a number of implications that such news coverage may have for the perceived legitimacy of EU institutions, and in particular the European parliament, among publics with more or less political interest and awareness.

\section{A new Europe: A new media landscape?}

The 2004 elections were the first taking place in the context of the media landscape in the enlarged EU-25. Most of the EU-15 countries have a pronounced public broadcasting system. A structural shift took place in Western European broadcasting in the 1980s and 1990s. The monopoly of the public broadcasters was challenged with the advent of commercial television. In 1980, all European countries (with the exception of Britain, Italy, and Luxembourg) still had public service broadcasting monopolies ${ }^{1}$ and by 2000 these had all come to an end [23].

In most of the countries that entered the European Union in 2004, commercial television was introduced in the 1990s, following a system of state-owned media that terminated with the events in the aftermath of the fall of the Berlin Wall. Slovenia introduced commercial television in 1991 [35], Poland in 1992 [12], the Czech Republic in 1993 [5], and Hugary in 1997 [14]. Given the rapid changes in the media landscape of the 'new' EU member states, by the elections in 2004 there were more similarities than differences between the media markets across the EU. The 'dual system' of broadcasting [30] in which public broadcasters and commercial stations co-exist and compete now virtually applies to all countries in the EU.

Table 1 provides an overview of the most significant public and private television stations in the EU-25 and emphasizes the strong presence of both types across the EU. The fundamentally changed European media landscape is an important backdrop for looking at both media use and consumption and media content. Public broadcasting is charged with a specific mission to provide information that facilitates public debate, civic engagement and democratic participation [4]. As a result, we might expect public broadcasters to devote more attention to political topics, including elections. This has been the case in, for example, Britain during general election campaigns where not only the BBC and but also ITV, its main competitor for the past four decades, operated on public service principles in covering campaigns [23-25, 29]. In the last few years, however, with the shift underway from terrestrial to digital channels, the field of competition has changed quite dramatically for both of these flagship channels and it is unclear that in the future ITV will continue to devote as much time to traditional political news or be required to follow public service obligations at election time.

Given the competitive structure of the media landscape in each of the EU's 25 countries, public broadcasters are also challenged to deliver products that attract substantial audience sizes. Concerns about ratings may lead to less emphasis on news about political issues if it may be of lesser interest to the public than news about sports, courts or crime, for example.

\footnotetext{
${ }^{1}$ Britain was unusual in that Independent Television (ITV) operated since the 1950s in the country and was designed originally to provide regional broadcasting in competition with the BBC's national channels. Independent Television News (ITN) was networked across all regional ITV companies on the same channel at the same times daily, so unlike most citizens on the Continent, viewers in Britain could choose between the public service channels (BBC1 and BBC2) and ITV for news for more than fifty years. That said, ITN has always been held to the same public service obligations as the BBC in reporting politics and election campaigns by the regulations under which commercial terrestrial television has been licensed [23,24], though some now question how long this will continue with the shift to digital technology.
} 
Table 1

Overview key public and private television in EU-25

\begin{tabular}{|c|c|c|c|}
\hline & Public & Mixed & Private \\
\hline Austria & ORF $1 / 2$ & & ATV+ \\
\hline Belgium/Flemish & VRT & & VTM \\
\hline Belgium/French & RTBF $1 / 2$ & & RTL \\
\hline Czech & CT $1 / 2$ & & Nova, Prima \\
\hline Cyprus & RIK 1/2 & & Lumiere, TVO, Sigma \\
\hline Denmark & DR $1 / 2$ & TV2 & \\
\hline Estonia & ETV & & Kanel 2, Muz TV, TV3 \\
\hline Finland & YLE $1 / 2$ & & MTV3, Nelonen \\
\hline France & France 2/3/5 & & Canal+, M6, TF1 \\
\hline Germany & $\mathrm{ARD}, \mathrm{ZDF}$ & & RTL, Sat1, Pro 7, Kabel 1 \\
\hline Greece & ET 1/3, NET & & ANT1, Mega \\
\hline Hungary & MTV-1 & & RTL, TV2 \\
\hline Ireland & RTE $1 / 2$, TG4 & & TV3 \\
\hline Italy & Rai $1 / 2 / 3$ & & Canale 5, Italia1, Rete 4 \\
\hline Latvia & LTV $1 / 7$ & & LNT, TV3 \\
\hline Lithuania & LTV $1 / 2$ & & LNK, TV3, TV4 \\
\hline Luxembourg & & & RTL \\
\hline Malta & TVM & & \\
\hline Netherlands & NED $1 / 2 / 3$ & & RTL 4/5, SBS6, Yorin, Veronica, Net5 \\
\hline Poland & TVP $1 / 2 / 3$ & & Canal+, Polsat, TVN \\
\hline Portugal & RTP1, A2 & & SIC, TVI \\
\hline Slovenia & TVS $1 / 2$ & & Kanal A, Paprika TV, Pop TV \\
\hline Slovakia & STV $1 / 2$ & & Joj TV, TV Markiza \\
\hline Spain & TVE $1 / 2$ & & Antenna 3, Canal+, Tele5 \\
\hline Sweden & SVT $1 / 2$ & & TV4 \\
\hline UK & BBC $1 / 2$ & & ITV, Channel 5 \\
\hline
\end{tabular}

Source: European Audiovisual Observatory (April, 2005).

\section{The continued importance of traditional media}

In the context of channel proliferation and increased choice of information sources via, for example, the Internet, the relevant question emerges of how important 'traditional' mass media actually are as sources of information. In the large countries on the borders of the EU, such as Ukraine and Russia, the Internet has played a very important role in giving visibility to traditional and new political parties. In Ukraine the Internet was a forum for opposing political voices, despite the comparatively low number of households with computers [26]. However, inside the European Union, Eurobarometer data very consistently show that the majority of citizens in Europe use television as their most important source of information about European affairs and most citizens also prefer television as the source of information in general (Eurobarometer 51-61).

During the campaign for the 2004 EP elections, television continued to play a key role. On average (see Fig. 1), 90\% of citizens in Europe reported having seen something about the elections and the campaign on television. $70 \%$ reported reading about the elections in newspapers. $8 \%$ reported searching for information about the elections on the Internet. Finally, 64\% reported being engaged in interpersonal discussion with friends, family or colleagues about the elections. These self-reported measures of campaign exposure in different media stress the continued significance of traditional media, and in particular television.

Only a small proportion of the Europeans interviewed around the time of the election sought information via the Internet. This small number suggests that currently there is a limited audience for EP election campaign information on the Internet. There are several possible explanations for this. The first possible 


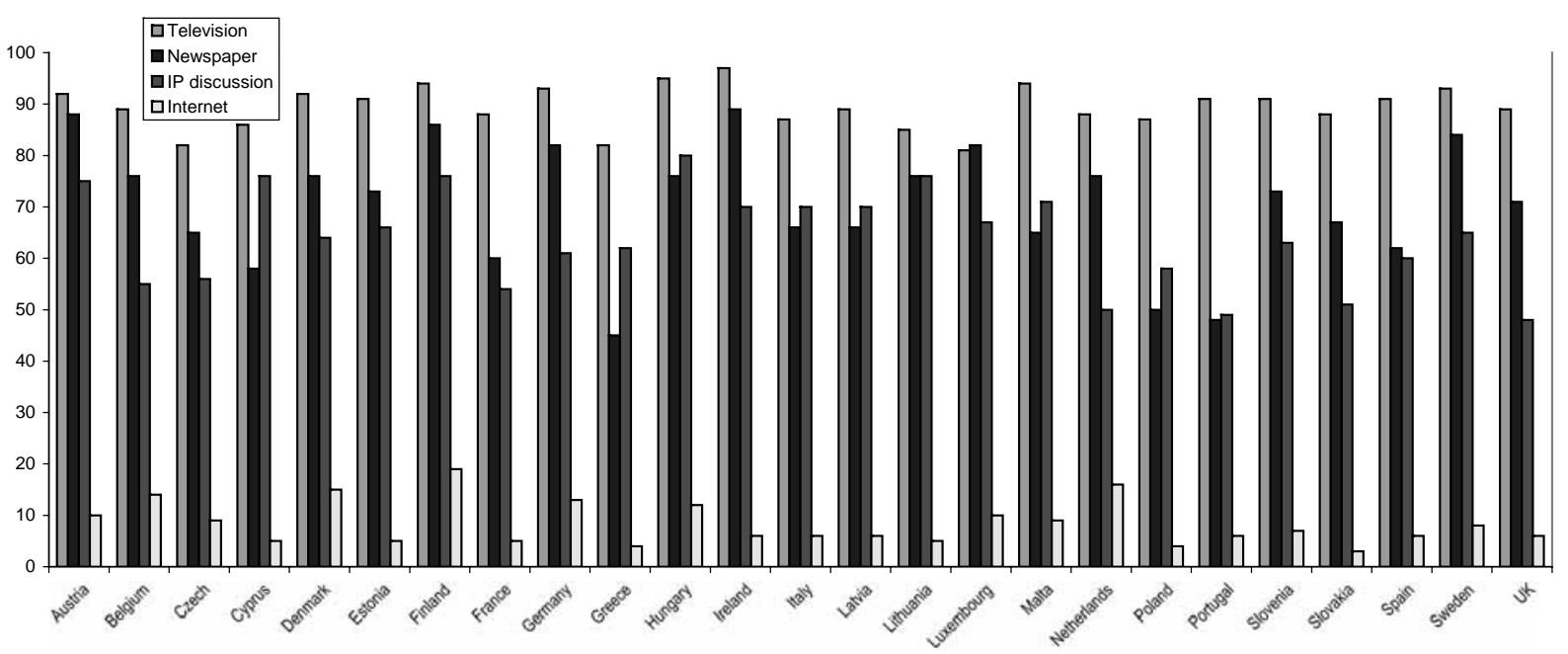

Note: data source EB162. Question: Have you read about (newspapers)/ seen or heard (television)/ discussed (interpersonal discussion)/ search for information about (Internet) the European Parliament elections.

Fig. 1. Use of information sources during the 2004 election campaign.

explanation rests on the issue of access. Across Europe, the Internet has not reached the same level of access as more traditional media such as television. Recent figures from Eurostat indicate that only $42 \%$ of households in the $25 \mathrm{EU}$ member states has access to the Internet and 38\% of EU citizens report using the Internet, on average, at least once a week. ${ }^{2}$ Secondly, whereas exposure to the campaign on television represents a passive form of exposure, citizens must actively seek out information about the EU elections on the Internet. Given the low salience and generally low visibility of EP elections, there is less chance of engaging citizens in the campaign such that they would turn to the Internet for further information. Finally, the availability of EU election information on the Internet may be another explanation for the lack of use during the campaign.

In terms of the impact of these various sources on information, engagement and participation, television is still likely to have the greatest impact. By contrast, the impact of the Internet on political engagement appears to be rather limited. While some find that Internet use enhances political participation [32], others find that it does not lead to other forms of political activity [3]. Results from a more recent study [16] counter Internet mobilization theorists and the authors conclude (p. 891) that "contrary to the growing chorus of technological enthusiasts that tout the Web as a "virtual" road to civic renewal, the Internet's effects are strongly linked to an individuals "real world" social environment". Indeed, there may be a limited impact of Internet political activity on engaging citizens in politics because those who take advantage of opportunities for virtual civic participation are those already most likely to participate in more traditional electoral activities. The internet's limited audience and it's questionable impact on voters suggest that, currently, television has the potential to have the largest impact on voters in terms of engaging them in EP elections.

\footnotetext{
${ }^{2}$ Figures on Internet access and use refer to 2004 and were obtained from Eurostat (eurostat.cec.ue.int).
} 


\section{European elections in the news}

Research in the past five years has started to give us an idea of how 'Europe' is reported in the news. The coverage of European affairs tends to be cyclical in nature with coverage of the EU being virtually absent from the news agenda, peaking around important EU events, and then vanishing off the agenda again $[7,17]$. This pattern of news coverage has for instance been found to apply to EU summits which are pivotal moments for EU decision making and where news coverage of EU affairs is much more visible than during 'routine periods' [11,20,27]. During other key events, such as national referendums on issues of European integration, EU news can take up a substantial part of the news agenda, especially in the final weeks of the campaign [8]. During routine periods, i.e. outside the referendum periods and when there are no scheduled events of the magnitude such as for example European Council meetings, EU politics is marginal in national television news [18,21].

Our knowledge about the way in which EP elections specifically are reported in the news pertains primarily to the first elections in 1979 and the 1999 elections. The analysis of the television coverage in the nine EC member countries in 1979 showed that the elections were virtually absent from the media agenda until the final weeks before the elections [30]. A study of the 1984 EP election coverage in Belgium and Denmark showed that, while the first elections did receive some degree of media coverage because of the novelty of the event, this aspect had already vanished with the second elections. As of the second EP elections, the campaign was 'nothing special' [15].

In 1999, a research team at The Amsterdam School of Communications Research, ASCoR, conducted an analysis of the most widely watched television news programs in the then $15 \mathrm{EU}$ member states in the two weeks leading up to the 1999 European elections. The results showed that the average time spent on the elections in the main evening news programs in all EU member states was about 7\%. Belgium, Britain, Germany, Ireland, the Netherlands, and Spain devoted even less than 5\% of the news to the elections. Austria, Denmark, Finland, France, Greece, Italy, and Sweden are somewhat above average, spending $8 \%$ to $13 \%$ of the news on European elections [11,20].

The 1999 study also enabled us to assess the presentation of the elections as either a national or a European contest. Looking at the presence of different actors in the news about the elections, we found no more than $7 \%$ of the actors in EU-related news were EU-level actors, 9\% 'other' (typically from NATO), and no less than $83 \%$ domestic actors. ${ }^{3}$ This strongly emphasizes the second-order national character of news content during the campaign for the European elections. In 1999, the European Union was an entity without a face as the European elections were overwhelmingly represented by domestic actors from the different countries [11].

The picture becomes only more dismal when we look at Europe's 'voice'. Arguably a mere count of the presence of actors is only part of the story about the importance of actors in the news. Quoting an actor in a news story gives her/him additional presence and weight. We therefore analyzed the distribution of quotes. We would expect that national politicians would try to take advantage of the free publicity opportunities afforded to them in the news during a European election campaign. In all the stories about the European elections, EU-level actors, including MEPs, delivered 4\% of the quotes whereas domestic actors provided $89 \%$. The study of the political actors in the news showed that when political actors were seen or were speaking they were most often national and not European-level political actors. In

\footnotetext{
${ }^{3}$ Members of the European Parliament in the period 1994-1999 were coded as EU-level actors while first time runners for the Parliament were coded as domestic actors as they are essentially not representing an EU institution. The latter category was rarely used.
} 
other words, the European Union had neither face nor voice during the campaign for the 1999 European elections [11].

All accounts, theoretical and empirical, argue for the necessity of visible EU affairs in the news in order to advance a viable public debate about European integration. Visibility of key democratic moments, such as elections, in the news is a pre-requisite for an enhancement of public awareness and possible engagement in EU politics. The need for visibility in national news media is emphasized by scholars in political communication [9] given the absence of a pan-European media system. As concluded elsewhere, "television, it seems, has not left the nation state" [18, p. 18]. Visibility of European affairs in the news represents an initial step towards public knowledge about the issues and procedures of the EU which in turn can increase accountability for policies and the legitimacy of decisions.

In order to address the descriptive, yet fundamental, research question of "how visible the $2004 \mathrm{EP}$ elections in the enlarged EU-25" were, a content analysis of the most important source of information for citizens in Europe, television, was conducted.

\section{2004 study: data and operationalization}

For this article we rely on data from an EU wide content analysis of the news media coverage leading up to the 2004 EP elections, a study specifically designed to be comparable across countries and over time. ${ }^{4}$ Here we report the visibility of the EP elections in the final two weeks leading up to the elections on the main national evening news broadcasts of the most widely watched public and private television station in each country. ${ }^{5}$

In total we cover 23 countries (all EU-25, except Cyprus (for technical reasons) and Luxembourg (for linguistic reasons)). With two news outlets per country, our sample consists of 49 television newscasts (in Belgium two French and two Flemish stations were included; in Finland and Germany four newscasts; in Spain and Poland three newscasts; in Austria, Greece, and Ireland one newscast). ${ }^{6}$ We base all analyses on length of the individual news story as part of the total length of each news program. Our unit of coding and of analysis is the individual news story, defined as a change of topic, typically introduced by the anchor person. An overview of missing days (due to technical problems) is provided in the Appendix.

Our key measure used here is visibility of the EP elections. Each news story was coded for topic. Coders utilized a three-layered list of topics to determine the topic of each story. For example a story about a homicide was assigned a code for 'homicide'. This specific category was part of a larger category (non-politically motivated crime) which was again part of a larger category (domestic crime). News about European elections was designated a range of codes that enables us to identify when a story was about the elections and what the specific topics of these stories were. For the current analysis, we rely on the most general classification and refer to all EP election news stories and stories about other EU topics collectively.

\footnotetext{
${ }^{4}$ The study was funded by research grants from the Dutch Science Foundation (VENI and VIDI grants), The EU civicactive project, The Halle Foundation and The Claus M. Halle Institute for Global Learning at Emory University, and the University of Amsterdam, to the principal investigators, Dr. Susan Banducci (Universiteit Twente), Prof. dr. Claes H. de Vreese (Universiteit van Amsterdam), and Prof. dr. Holli A. Semetko (Emory University).

${ }^{5}$ The study also involved a content analysis of national newspapers but in this article we focus attention on the main source of information for citizens, television.

${ }^{6}$ For Austria we include only ÖRF which has the largest share. The private ATV has a negligible news service and minimal audience share [33].
} 
For this large scale, cross-national study we relied on coders who were mostly native speakers of the different languages. Coders were trained with the codebook for the study developed by the principal investigators, and only when their coding was of sufficient quality (assessed by coder tests that were matched with master codes completed by the coder trainer team), did actual coding commence. ${ }^{7}$ Given the challenges in cross-national content analysis (see [19]), coders were closely monitored and intercoderreliability tests were conducted. The results of these tests were generally in the 80-90\% range of agreement for specific topic codes and thus higher for the more 'general level' categories reported here.

\section{Results}

How visible were the 2004 EP elections in national television news? We answer this question in a cross-nationally and temporally comparative fashion. The EU-average in 2004 was that $9.8 \%$ of the main evening news in the two weeks leading up to the election was devoted to EU news. Of this, around $80 \%$ was specifically devoted to the EP elections. ${ }^{8}$

Figure 2 shows the visibility of the elections in 2004 in the $23 \mathrm{EU}$ countries under analysis. The figure shows the time devoted to EU news as the percentage of the length of all television news stories coded, including sports coverage and the weather forecast. The EU-wide average contains significant crossnational variation. In Greece, for example, the elections took up $21 \%$ of the news, while in Germany, the elections took up 3\% of the news. In addition to Greece, the elections were most visible in Denmark, Slovakia, Austria, and Ireland, taking up more than $15 \%$ of the news in these countries. In addition to Germany, the elections were least visible in Belgium and the Czech Republic with less than five percent of the news devoted to the elections.

The average visibility of EU news in 2004 was higher in the new member states (10.4\% on average) than in the old member states $(9.2 \%)$. This is also evident when considering the individual countries. From the new member states, seven out of nine countries analyzed show more than ten percent EU news, whereas only seven out of 14 of the old member states come across that threshold. In comparison with 1999 , the overall visibility in the 15 'old' member states increased slightly from $7 \%$ in 1999 to $9 \%$ in 2004. Visibility decreased in Portugal, Italy and France, but increased in the remaining EU-15 member states. Comparing the visibility of the elections in the news programs of public and private broadcasters we found public broadcasters to devote more time to the elections than their private counterparts. In the 'new' countries $10.5 \%$ of the time on public news was devoted to the elections while this was $6.8 \%$ in the 'old' countries. Of the private news, $8.4 \%$ of the time was devoted to the elections in the new and $5.2 \%$ in the old member states.

The importance of elections being visible in the news is of course augmented if voters are also aware of the coverage. In Fig. 3 we look at the relationship between the visibility of the EP elections (as outlined

\footnotetext{
${ }^{7}$ Coding was conducted by trained and supervised coders working for MedienTenor in Bonn (Germany), Dover (England), and Ostrawa (Slovakia), with supervision by and close cooperation with the principal investigators.

${ }^{8}$ In our analyses we rely on time-based measures. All percentages are percentages of the total length of broadcast news in each country. This is to keep our findings comparable. News in some countries is 15 minutes long while in others up to 60 . In some countries news stories are short on average and in other countries long. In terms of the substantial outcome, we note that an n-based (i.e. number of stories) analysis showed an overall average of $8.3 \%$. In our current analysis this is $9.8 \%$ which suggests that EU related news is on average longer than the most news stories. Moreover we found that based on n-measures, the elections took up $10.4 \%$ of the news in new member states, in time this was also $10.4 \%$. For the old member states however, the n-based measured was $6.9 \%$ while the time based result was $9.2 \%$ suggesting that EU news in the old member states was less frequent in terms of number but significantly longer than other news.
} 


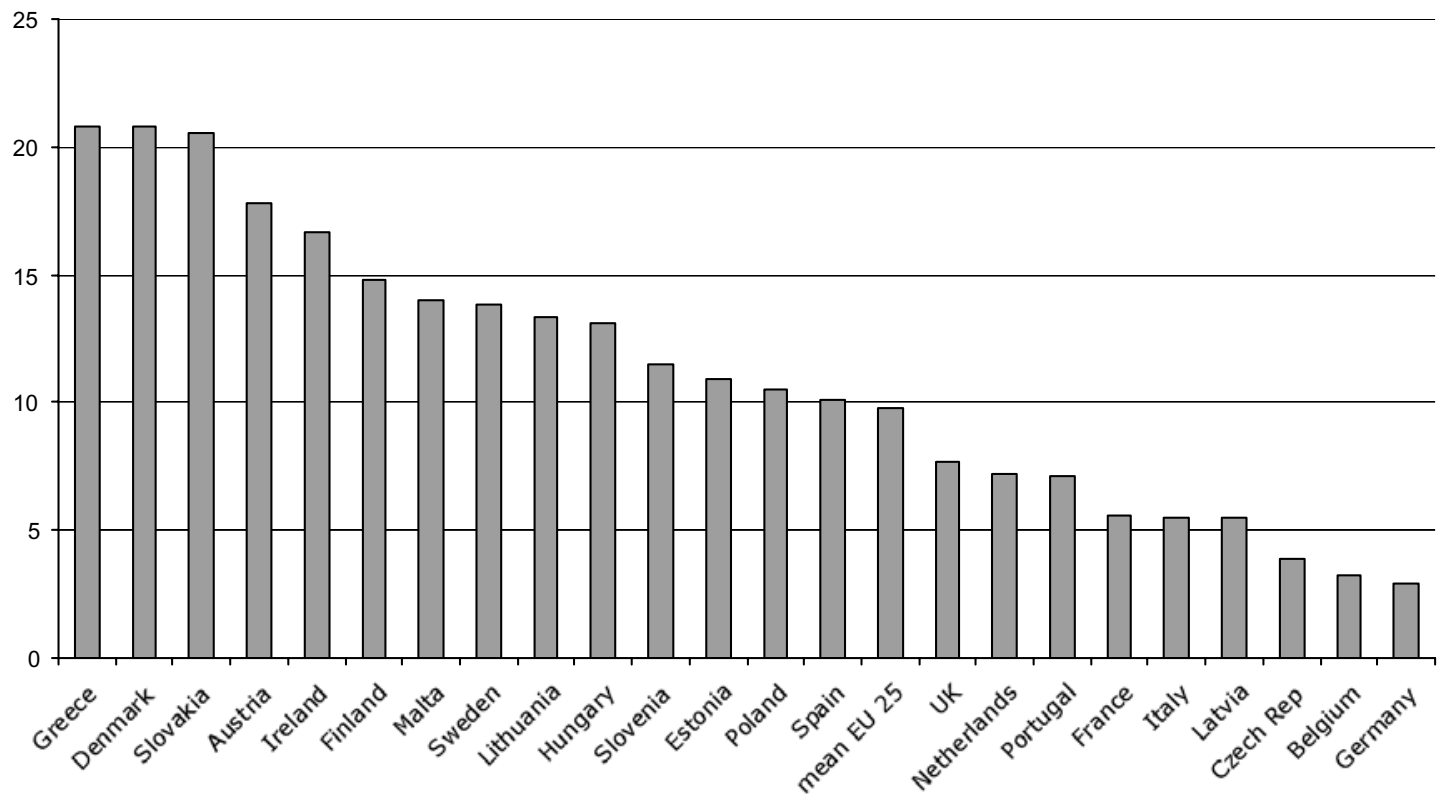

Note: Values are story length-based percentages. Period: 12 days leading up to the June 2004 elections.

Figure displays EU news (EP election news is about 80 percent of the total EU news).

Fig. 2. Visibility of European elections on television news.

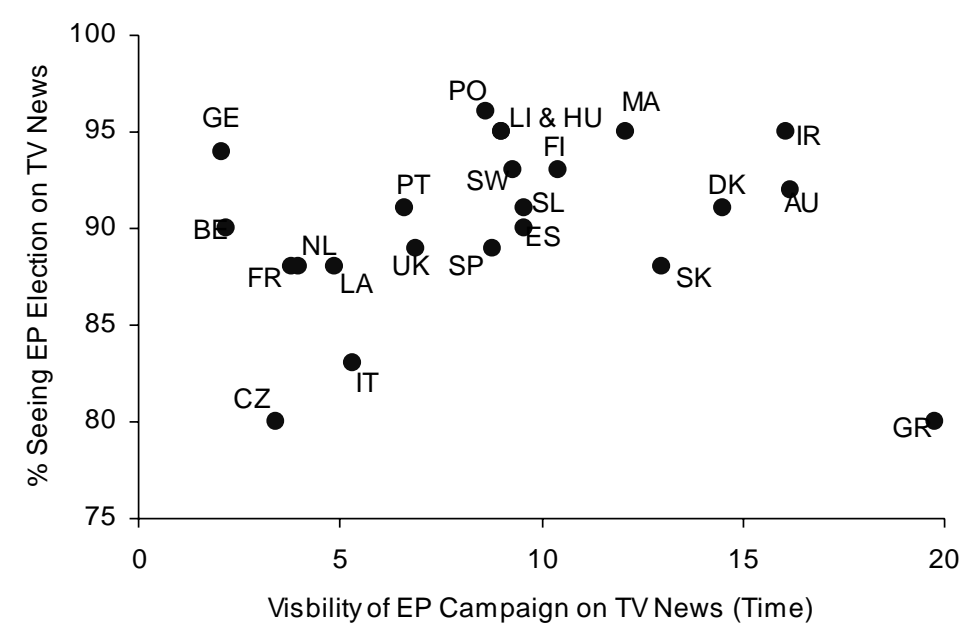

Fig. 3. Relationship between campaign visibility on TV news and reports of seeing EP campaign on TV News.

in Fig. 2) and the percentage of respondents reporting that they saw something about the campaign on television (see Fig. 1). ${ }^{9}$ Disregarding the case of Greece (where the elections were highly visible (relatively speaking) but respondents did hardly report seeing something about the elections), in the

\footnotetext{
${ }^{9}$ For this analysis we rely on Eurobarometer 162.
} 
remaining countries we find a positive relationship between the amount of news about the elections on television and citizens reporting being exposed to the elections through television. ${ }^{10}$ For every percentage (one unit) increase in the volume of television news coverage of the elections as a percentage of the total length of news programs in each country, there is an increase in the proportion of respondents reporting seeing something about the elections by about $0.5 \%$.

\section{Discussion}

In this article the competitive television news market in the EU was introduced to provide a background for television's coverage of the 2004 EP elections. This introduction highlighted that the elections coverage in the entire EU takes place in dual systems of broadcasting in which privately and publicly funded networks compete. We next stressed the continued importance of television as a key resource for European citizens for receiving information about European integration and the EU. Television is not only the most widely cited source of information, it is also television that most citizens point to when asked whether and if they had seen or heard anything about the EP elections.

The importance of television is almost paradoxical when considering the minimal attention that EU news has received in television news previously. In this study we reported key findings from a large-scale content analysis of the news media's coverage of the EP elections. We specifically analyzed the visibility of the elections in national television news to assess the information available to citizens across Europe in their most preferred and most frequently used source of information. The analyses demonstrated that if we take the overall average amount of coverage of the campaign in the main evening flagship television news programs, the elections in 2004 were generally more visible than they were in 1999 in the 'old' 15 EU member states. In the 'new' member states visibility was, on average, higher than in the 'old' member states. This finding dovetails with previous research suggesting that the novelty of EP elections, i.e. the first elections after joining the EU, tends to be covered more intensively $[11,20]$. Moreover we found that public broadcasters devoted more attention to the elections than private broadcasters, albeit at different levels in the 'old' and the 'new' countries. This finding dovetails both research on the content of public and private news programs in general and on the media's attention for European news in particular [18], and confirms that in a competitive media landscape news about European elections is more likely to come from public than private channels.

From a standpoint of democratic citizenship, a campaign has the potential to inform and mobilize voters to take part in the process of electing representatives. The media play a crucial role in this process. The EU also relies on the media to indirectly strengthen its legitimacy by increasing citizens' awareness of its activities and policies. In 1999, doubt was raised if the media fulfilled this role [11]. In some countries in 1999, the picture painted of the news coverage of the European elections was gloomy from the perspective of the coverage of the campaign in the most popular media outlets providing information to citizens. The European elections were given relatively low priority in the news, they rarely made the opening of the news bulletins, the coverage was domestic in nature with most stories taking place in the home country and addressing issues with implications for the home country. Few representatives of EU institutions made it into the news and these EU actors were rarely quoted.

In 2004, the visibility of the elections generally increased except in a few countries. This finding provides an important backdrop against which to interpret studies focusing on 'new media' and in

\footnotetext{
${ }^{10}$ A bivariate regression analysis explained $\left(\mathrm{R}^{2}\right) 20 \%$ of the variance in the audience responses.
} 
particular the role of the Internet. On television, there is considerable variation in the amount of attention given to European elections. Together with the information provided by newer media, television news forms a key source of information for European citizens during the campaign for European elections.

Important questions to be addressed are "how and under which conditions news affect audiences and voters?'. The literature on campaign effects suggests that news and campaigns can either mobilize or demobilize voters, and there is some evidence from national elections that both processes may be happening during a campaign and may depend on whether one relies on news on public service or competing channels [1]. Such effects are not only contingent upon the individual characteristics of voters (such as political interest [13] or political awareness [34]), but also depend on the diet of information provided by the media. It has been demonstrated that television in particular is capable of contributing to turnout in European elections [22], especially among citizens with lower levels of political interest and awareness who may be 'trapped' into watching election news on television. Based on the 1999 European parliamentary election, and most previous campaigns, where there was little in the way of coverage of the campaign on main evening television news, uninterested citizens had few opportunities to accidentally come across interesting news about the elections that might boost their interest and awareness [22]. Such questions still have to be addressed for the 2004 elections in the enlarged Europe, but we emphasize that any effects of mass mediated communication, positive or negative, should be assessed in the context of detailed information about content of traditional media and the simultaneous influence of new media.

\section{References}

[1] K. Aarts and H.A. Semetko, The Divided Electorate: Effects of Media Use on Political Involvement, The Journal of Politics 65(3) (2003), 759-784.

[2] W.L. Bennett and R.M. Entman, Mediated politics. Communication and the future of democracy, Cambridge University Press, Cambridge, 2001.

[3] B. Bimber, Information and political engagement in America: The search for effects of information technology at the individual level, Political Research Quarterly 54(1) (2001), 53-67.

[4] K. Brants and E. de Bens, The status of TV broadcasting in Europe, in: Television across Europe, J. Wieten, G. Murdock and P. Dahlgren, eds, Sage, London, 2000, pp. 7-22.

[5] J. Culík, The Czech Republic, in: The media in Europe. The Euromedia Handbook, M. Kelly, G. Mazzoleni and D. McQuail, eds, Sage, London, 2004, pp. 31-42.

[6] R. Dalton and R.D. Duval, The Political Environment and Foreign Policy Opinions: British Attitudes Toward European Integration, 1972-1979, British Journal of Political Science 16 (1986), 113-134.

[7] C.H. de Vreese, J. Peter and H.A. Semetko, Framing politics at the launch of the euro: A cross-national comparative study of frames in the news, Political Communication 18(2) (2001), 107-122.

[8] C.H. de Vreese and H.A. Semetko, News Matters: Influences on the Vote in the Danish 2000 euro referendum campaign, European Journal of Political Research 43(5) (2004), 699-722.

[9] C.H. de Vreese, Framing Europe: Television news and European integration, Aksant Academic Publishers, Amsterdam, 2002.

[10] C.H. de Vreese and H.G. Boomgaarden, Media effects on public opinion about the enlargement of the European Union, Journal of Common Market Studies (2005, forthcoming).

[11] C.H. de Vreese, E. Lauf and J. Peter, The media and European Parliament elections: Second-rate coverage of a secondorder event? in: European elections and domestic politics. Lessons from the past and scenarios for the future, W. van der Brug and C. van der Eijk, eds, University of Notre Dame Press, Paris, 2005.

[12] K. Jakubowicz, Poland, in: The media in Europe. The Euromedia Handbook, M. Kelly, G. Mazzoleni and D. McQuail, eds, Sage, London, 2004, pp. 169-179.

[13] K.F. Kahn and P.J. Kenney, Do Negative Campaigns Mobilize or Suppress Turnout? Clarifying the Relationship between Negativity and Participation, American Political Science Review 93(4) (1999), 877-889.

[14] B. Kiss, Hungary, in: The media in Europe. The Euromedia Handbook, M. Kelly, G. Mazzoleni and D. McQuail, eds, Sage, London, 2004, pp. 103-114.

[15] P. Leroy and K. Siune, The role of television in European elections: the cases of Belgium and Denmark, European Journal of Communication 9 47-69. 
[16] M.C. Nisbet and D.A. Scheufele, Political talk as a catalyst for online citizenship, Journalism and Mass Communication Quarterly 81(4) (2005), 877-896.

[17] P. Norris, A virtuous circle. Political communications in postindustrial societies, Cambridge University Press, Cambridge, 2000.

[18] J. Peter and C.H. de Vreese, In search of Europe - A cross-national comparative study of the European Union in national television news, Harvard Journal of Press/Politics 9(4) (2004), 3-24.

[19] J. Peter and E. Lauf, Reliability in Cross-National Content Studies, Journalism and Mass Communication Quarterly 79(4) (2002), 815-832.

[20] J. Peter, E. Lauf and H.A. Semetko, Television Coverage of the 1999 European Parliamentary Elections, Political Communication 21(4) (2004), 415-433.

[21] J. Peter, H.A. Semetko and C.H.de Vreese, EU Politics on Television News: A cross-national comparative study, European Union Politics 4(3) (2003), 305-328.

[22] K. Schoenbach and E. Lauf, The "Trap" Effect of Television and Its Competitors, Communication Research 29 (2002), 564-583.

[23] H.A. Semetko, Great Britain: The End of the News at Ten and the Changing News Environment, in: Democracy and the Media: A Comparative Perspective, R. Gunther and A. Mughan, eds, Cambridge University Press, Cambridge, 2000, pp. 343-374.

[24] H.A. Semetko, The UK Media System, in: Encyclopaedia of International Media and Communications, D.H. Johnston, ed., Academic Press, New York, 2003.

[25] H.A. Semetko, Political Balance on Television: Campaigns in the US, Britain and Germany, Harvard International Journal of Press/Politics 1(1) (1996), 51-71.

[26] H.A. Semetko and N. Krasnoboka, The Political Role of the Internet in Societies in Transition: Russia and Ukraine, Party Politics 9(1) (2003), 77-104.

[27] H.A. Semetko and P.M. Valkenburg, Framing European Politics: A Content Analysis of Press and Television News, Journal of Communication 50(5) (2000), 93-109.

[28] H.A. Semetko, C.H. de Vreese and J. Peter, Europeanised Politics - Europeanised Media? The Impact of European Integration on Political Communication, West European Politics 23(4) (2000), 121-140.

[29] H.A. Semetko, M. Scammell and P. Goddard. Television, Parliamentary Affairs 50(4) (1997), 609-615, (Special issue entitled "Britain Votes 1997").

[30] K. Siune, The campaign on television: What was said and who said it? in: Communicating to voters. Television in the first European parliamentary elections, J. Blumler, ed., Sage, London, 1983, pp. 223-240.

[31] K. Siune and O. Hultén, Does public broadcasting have a future? in: Media policy. Convergence, concentration, commerce, D. McQuail and K. Siune, eds, Sage, London, 1998, pp. 23-37.

[32] C.J. Tolbert and R.S. McNeal, Unravelling the effects of the internet on political participation, Political Research Quarterly 56(2) (2003), 175-185.

[33] J. Trappel, Austria, in: The media in Europe. The Euromedia Handbook, M. Kelly, G. Mazzoleni and D. McQuail, eds, Sage, London, 2004, pp. 4-15.

[34] J. Zaller, The Nature and Origins of Mass Opinion, Cambridge University Press, New York, 1992.

[35] V. Zei, Slovenia, in: The media in Europe. The Euromedia Handbook, M. Kelly, G. Mazzoleni and D. McQuail, eds, Sage, London, 2004, pp. 214-223. 


\section{Appendix: Missing days television news}

\begin{tabular}{lll} 
Country & Outlet & Missing \\
Austria & ORF & None \\
Belgium/Flemish & Het Journaal (VRT), VTM Nieuws & None \\
Belgium/French & JT Meteo, Le Journal & None \\
Czech & TV Ceska, TV Nova & None \\
Cyprus & No television & TVAvisen June 1 / TV2 Nyhederne June 5 \\
Denmark & TV-Avisen (DRTV1), TV2 Nyhederne & Kanal 2 June 3, 12 \\
Estonia & ETV, Kanal 2 & Yle June 1 / MTV3 June 4, 6, 7 / Ruutu4 June 1,2 \\
Finland & Yle, MTV3, Ruutu4 & F2 June 5 \\
France & LaJournal (TF1), Le Journal (F2) & None \\
Germany & ARD Tagesschau, ZDF Heute, RTL Aktuell, Sat1 & ET1 June 10, 13 \\
Greece & ET1 news & None \\
Hungary & MTV, TV2 & None \\
Ireland & RTE1 & TG5 June 1 \\
Italy & TG1, TG5 & LatTV, Latvia Televizija June 11 \\
Latvia & Lat TV, Latvija Televizija & LRTV June 10 / TV3 June 4-7, 11 \\
Lithuania & LRTV, TV3 & Super 1 June 2 \\
Malta & TVM, Super1 & None \\
Netherlands & NOS Journaal, RTL nieuws & None \\
Poland & TVPSA, POLSAT & RTP1 June 1 \\
Portugal & RTP1, SIC & None \\
Slovenia & RTV, POPTV & None \\
Slovakia & STV1, Markiza & TVE June 1, 2, 6, 8, 9 \\
Spain & TVE, Antenna3, Tele5 & TV4 June 4-13 \\
Sweden & Rapport TV2, Nyheterne (TV4) & None \\
UK & BBC1, ITV & Super 1 June 2 \\
Malta & TVM, Super1 & The \\
\hline
\end{tabular}

Note: a total of 38 programs are missing which amounts to about $6 \%$ of the total sample. 